International Journal of Advanced Academic Research | ISSN: 2488-9849

Vol. 7, Issue 5 (May, 2021) | www.ijaar.org

Journal DOI: www.doi.org/10.46654/ij.24889849

Article DOI: www.doi.org/10.46654/ij.24889849.s7523

\title{
SERVICE QUALITY DIMENSIONS AND CUSTOMER SATISFACTION: A STUDY OF SELECTED HOTELS IN OSUN STATE, NIGERIA
}

\author{
Olasehinde Akeem ${ }^{1}$, Ighomereho O. Salome ${ }^{2}$ and Adeniji P. Olufunke ${ }^{3}$ \\ ${ }^{1}$ Department of Marketing, Federal Polytechnic, Ede, Osun State, Nigeria \\ ${ }^{2}$ Department of Business Administration and Marketing, Redeemer's University, Ede, Osun \\ State, Nigeria \\ ${ }^{3}$ Department of Tourism Studies, Redeemer's University, Ede, Osun State, Nigeria \\ Corresponding Author's Email: ighomerehoo@run.edu.ng, +2348028427765
}

\begin{abstract}
Customer satisfaction is a critical success factor in the service sector and it is one of the important marketing metrics. Satisfying the needs of customers is very important for the survival and continued existence of businesses especially hotel services. The purpose of this study is to examine the relationship between service quality dimensions and customer satisfaction with respect to hotel services in Osun State, Nigeria. A questionnaire was used to obtain data for the study. Six hundred and twenty - four (624) copies of the questionnaire were administered, but six hundred (600) representing ninety - six per cent (96\%) were returned and used for the analysis. The data collected were analysed using descriptive statistics and multiple regression analysis. It was found that responsiveness is the most highly rated service quality dimension $(82.3 \%$, mean $=4.30, S D=0.05)$, while empathy has the lowest perception value $(65.6 \%$ mean $=4.11, S D=0.06)$. The result also revealed that majority of the customers $(70.9 \%)$, were satisfied with the hotel services in Osun State. Furthermore, it was discovered that the five service quality dimensions have a significant positive relationship with customer satisfaction. The study clearly showed that service quality plays an important role in customer satisfaction with hotel services. Therefore, managers should give more attention to the five (5) service quality dimensions namely: tangibility, reliability, responsiveness, assurance and empathy.
\end{abstract}

Keywords: Service quality, customer satisfaction, expectation, perception, hotels 
Journal DOI: www.doi.org/10.46654/ij.24889849

Article DOI: www.doi.org/10.46654/ij.24889849.s7523

\section{INTRODUCTION}

Marketing processes and activities are aimed at attracting, satisfying and retaining customers. These can only be achieved with excellent customer service or service quality (Kotler, 2007). Quality has attracted the attention of practitioners and academicians over the years but mostly in the manufacturing sector at the early stage (Minh, Nguyen, Phan \& Yoshiki, 2015). Since the 1980s, however, the importance of quality in the service sector has been widely recognized in the literature due to its great impact on different dimensions of business performance (Minh et al., 2015). Service quality is an assessment of how well a delivered service conforms to customers' expectations. It is crucial in any business as it helps to create a bond between the business and its customers. It is also essential for success and survival in a competitive marketing environment as it influences the level of relationship between the customer and the firm (Shimekit, Wondoson \& Seid, 2016). Hence, it has been opined that to gain competitive advantage, businesses need to satisfy customers and meet their expectations of service quality (Weitz \& Wessley, 2002). As noted by Osayawe (2006) high service quality improves corporate image, enhances customer satisfaction, cross-selling opportunities, decreases customer defection, increases chances of word-of-mouth recommendation and maintenance of positive long-term customer relationships.

Experience over the years has shown the discontentment of some customers, about their unmet expectations as promised by some hotels. This has impacted negatively on the growth and development of the hotel business in Nigeria when compared to other countries. Furthermore, the service industry in Nigeria and other parts of the world are faced with the challenge of giving tangible evidence of quality service (Suciptawati, Paramita \& Aristayasa, 2019). As such, service providers are using atmosphere, automation and employee empowerment and differential pricing to create memorable experiences, thus giving customers something to hold onto and equally look forward to (West, Ford \& Ibrahim, 2010). The service quality dimensions (tangibility, reliability, responsiveness, assurance and empathy) are seen as the basic measure of service quality dimensions to determine customer satisfaction in the service industry. These service quality dimensions are given the attribute of physical product to overcome the challenge of tangibility. In addition to tangibility, hotel customers like any other industry, needs reliability, responsiveness, assurance, and empathy. It requires a lot of individualized attention to their numerous guests. However, the management of some hotels has not been giving much attention to this unique aspect of the business, which can be a game - changer for the development of the business. Hotel business is unique in the sense that customers will always need the attention of the service provider throughout their stay in the hotel facility. Therefore, showing empathy to the various needs of the guest stands to put the business at a competitive edge.

The intangibility nature of services and the need to satisfy customers make this study a necessity. The level of experience of essential service elements may determine the level of customer satisfaction. It has been noted by scholars that service quality has a positive effect on customer satisfaction (Suciptawati, Paramita \& Aristayasa, 2019). However, only very few studies have been able to explore and highlight the variables that constitute service quality in the determination of customer satisfaction in the Nigeria hotel industry. Moreover, most of the studies on customer satisfaction are centred on five-star hotels located in the country's capital and metropolitans, neglecting other categories of hotels in the hinterlands (Jawabreh, Jahmani, Khaleefah, Alshatnawi \& Abdelrazaq, 2020). Information on the extent to which customer satisfaction is impacted by service quality provided by this category of hotels will help the 
Journal DOI: www.doi.org/10.46654/ij.24889849

management of the hotels and other allied hospitality service providers in understanding the expectations of customers and ensuring that they meet up with this level of expectation. Consequently, the objectives to be achieved in this study are to:

i. Examine the perception of hotel service quality in Osun State, Nigeria.

ii. Determine the level of satisfaction of hotel customers in Osun State, Nigeria.

iii. Investigate the impact of service quality dimensions (tangibility, reliability, responsiveness, assurance and empathy) on customer satisfaction in Osun State, Nigeria.

\section{LITERATURE REVIEW}

\subsection{Service Quality}

Service quality is defined as customers' overall assessment of the utility of a service based on the perceptions of what is received and what is given. It emanates from customers' comparison between prior expectations about the service and their perceptions after the actual experience of service performance (Hanzaee \& Mirvaisi, 2011). Service quality contributes to positive business outcomes such as customer satisfaction, and favourable consumer behaviour such as repurchase and positive word-of-mouth. Zhang and Tang (2006) stated that if a business can figure out what customers like and deliver it the same way every time, the customers will come back, tell others about the service and the company will become more successful. Thus, service quality is a competitive strategy and means of differentiating between objectively similar alternatives in the market place (Zeithaml \& Bitner, 2003). In today's competitive marketing environment, service quality is very significant in attracting and retaining customers. Service providers often assess the service quality provided to their customers to quickly identify problems, improve their services and to assess customer satisfaction better. Gefan (2002) noted that service quality is the subjective comparison that customers make between the quality of the service they want to receive and what they get. Service quality can also be described as the inclusion of all specified features, as defined for a service and its ability to satisfy the given needs. Delivering quality service means conforming to customer expectations on a consistent basis, and it is a measure of how well the service level delivered matches customer expectations. Customers will judge the quality of a service as low if performance does not meet expectations and high when performance exceeds expectations (Jayaraman, Shankar \& Hor, 2010)

The dimensions for measuring service quality have been of interest to many researchers. Due to the multi-dimensional nature of service quality, there is lack of consensus on its measurement. However, the most extensively used dimensions of service quality is the one developed by Parasuraman, Zeithaml \& Berry (1988). It is usually referred to as the SERVQUAL model. It has been widely acknowledged and applied in various service settings for a variety of industries. The model consists of five service quality dimensions and they are conceptualized as follows:

Tangibility: The appearance of physical facilities, equipment, and personnel, including the design of the office.

Reliability: The ability to perform the promised service dependably, accurately and consistently.

Responsiveness: The willingness to help customers and to provide prompt service. 
Journal DOI: www.doi.org/10.46654/ij.24889849

Article DOI: www.doi.org/10.46654/ij.24889849.s7523

Assurance: The knowledge and courtesy of employees and their ability to inspire trust and confidence.

Empathy: The caring and individualized attention the firm provides its customers.

\subsection{Customer Satisfaction}

Customer satisfaction is a marketing philosophy used in both manufacturing and services industries. Recent research efforts show that customer satisfaction studies are fast becoming more popular in services marketing because of its role as a strategy or means of boosting business performance and leveraging competitive advantages (Choi and Chou, 2001; Hansen and Sand, 2008; Liu and Tsai, 2010). The popularity of customer satisfaction can also be attributed to its potency in providing business owners and managers with a metric that they can use to measure, manage and improve performance. There are diverse opinion on the meaning and concept of customer satisfaction. In the view of Suciptawati, et al. (2019), customer satisfaction is the outcome of service quality. Méndez-Aparicio, Jiménez-Zarco, Izquierdo-Yusta and Blazquez-Resino (2020) see customer satisfaction as a psychological outcome emerging from customer's experience. Siddiqui and Sharma (2010) noted that satisfaction and dissatisfaction could be described as customer's fulfilment response, that is, the degree to which the level of fulfillment is pleasant or unpleasant. Zeithaml and Bitner (2003) view customer satisfaction as the evaluation of a service in terms of whether it has met a need or want.

Lovelock, Patterson and Walker (2001) noted that customer satisfaction is a person's feelings of pleasure or disappointment resulting from comparing a product's perceived performance about his or her expectations. It is the internal feeling customers have when they assess the service provided by a firm. If the perceived product performance is less than expected, customers will be dissatisfied. On the other hand, if the perceived performance exceeds expectations, customers will be satisfied. If the perceived expectations are met with performance, customers are in an indifferent or neutral stage. Customer satisfaction is generally related to the "appropriateness" of the product because appropriateness is individualistic. There will be variations across customers, such that some customers may evaluate a product as satisfying while others as not satisfying. The level of customer satisfaction is different between different customers because each of them has their personal needs, demands as well as experiences. Therefore, to achieve customer satisfaction, it is vital to recognize and anticipate customers' needs and to be able to satisfy the customer (Shimekit et al., 2016)

Kotler and Lane (2009) argued that the identification of the determinants of customer satisfaction is a primary concern for service providers. It has been a critical determinant in explaining why customers leave or stay with an organization (Khan, Hussain \& Yaqoob, 2013). Some unsatisfied customers may choose not to stop patronizing because they do not expect to receive better service elsewhere. In contrast some satisfied customers may look for other providers if they believe they can get better services elsewhere. Therefore, the more positive the level of customer satisfaction is, the more likely the repurchase of a product (Sheng \& Wu, 2011). Several empirical studies (Juwaheer and Ross, 2003; Mehra and Ranganathan, 2008; Hossain, 2012) have identified service quality as an antecedent of customer satisfaction. It has been suggested that perceived higher service quality will result in customers evaluating a product in a more positive way and as having high value. Higher 
Journal DOI: www.doi.org/10.46654/ij.24889849

perceived values and positive evaluation of service will, in turn, enhance customer satisfaction.

\subsection{The Hotel Industry}

The hotel business is one of the most critical sectors in the tourism and hospitality industry. Chakravarti (2011) defined hotel as an establishment that provides paid lodging on a short term basis. It is a commercial enterprise that is responsible for the provision of sleeping accommodation and if required entertainment, food and drink. Hotels receive different kinds of guest who are able and willing to pay a reasonable sum for the facilities or services provided and who are in a fit state to be received. Enlightenme, (2014) quoted the World Tourism Organization (UNWTO) stating that the global number of hotel rooms has grown from 14 million to 17 million between 1997 to 2005 and the figure is expected to increase astronomically by the end of 2020 . The growth in the hotel industry has been identified as one of the main facilitators in the development of tourism and hospitality industry as a whole. Looking at the various types of accommodation available to the tourist, hotel is the largest and most visible. It is usually viewed as an establishment which provides lodging, food and beverage services on a pay basis to guests who are only for a short stay. However, the modern perception of a hotel is more complex than this because not all hotels provide services such as food and beverages, at the same time. Some hotels even provide additional services such as conference rooms to their guests (Cooper, Fletcher, Fyall, Gilbert \& Wanhill, 2008). In this study, the definition given by the European Commission was adopted. European Commission (2014) defined a hotel as a unit which provides stay for visitors, typically on a daily or weekly basis, principally for short stays. Furthermore, the Commission gives details of services provided by such units to include regular cleaning and bed-making as well as offering food, beverages, parking, laundry services and recreational services to the guests.

\subsection{Conceptual Model}

Figure 1: Conceptual Model of Service Quality and Customer Satisfaction

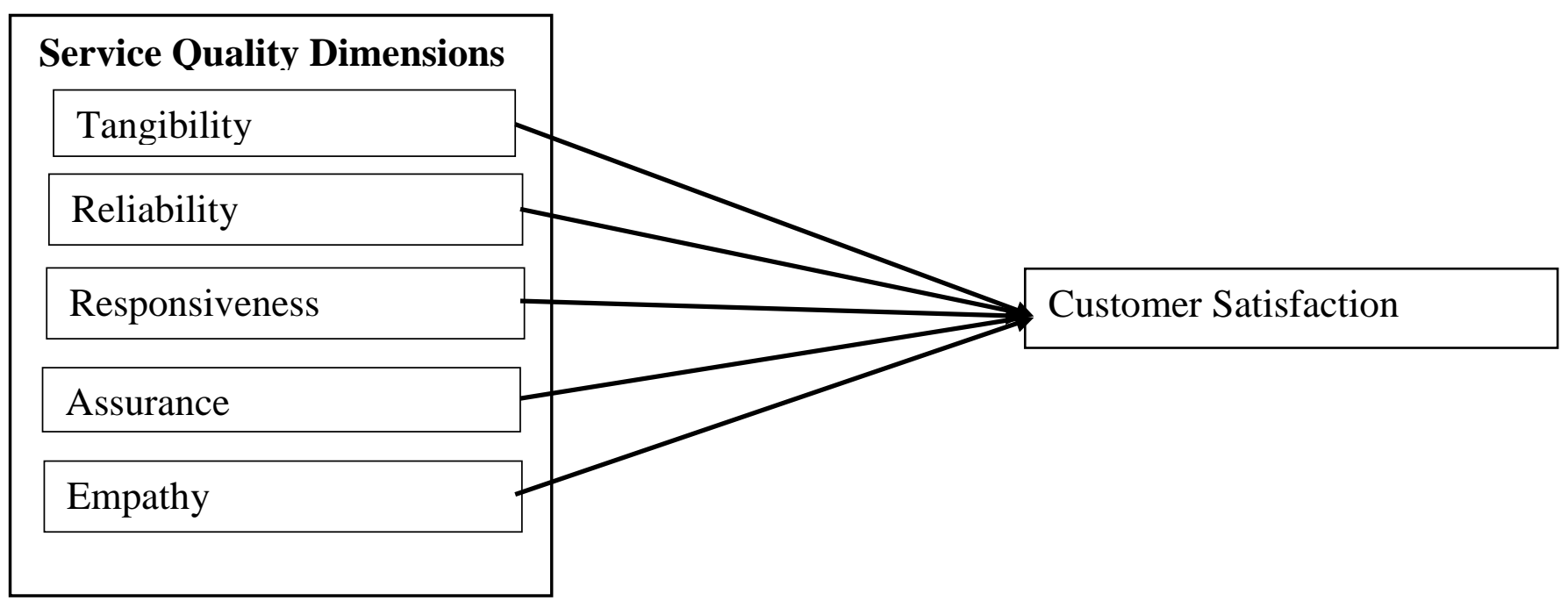

Source: Authors (2020)

This study is based on the conceptual model depicted above. The model defines and explains the relationship between service quality dimensions and customer satisfaction. Service 
Journal DOI: www.doi.org/10.46654/ij.24889849

Article DOI: www.doi.org/10.46654/ij.24889849.s7523

quality which consists of five quality dimensions jointly determine the service quality offered by the hotels in Osun State and it is believed that they influence customer satisfaction.

\subsection{Theoretical Framework}

This study is anchored on the Theory of Expectations-Confirmation/Disconfirmation of Customers Satisfaction. Oliver (1980, 1997) proposed the Expectancy-Disconfirmation Theory as the most promising theoretical framework for the assessment of customer satisfaction. The theory implies that customers purchase products with pre-purchase expectations about the anticipated performance. The product is judged using the standard expectation level. That is, using the product and comparing action against expectations. If the outcome matches the expectation, confirmation occurs. Disconfirmation occurs where there is a disparity between expectation and outcomes. A customer is either satisfied or dissatisfied as a result of a positive or negative difference between expectations and perceptions. Thus, when service performance is better than what the customer had initially expected, there is a positive disconfirmation between expectations and performance, which results in satisfaction but when service performance is as expected; there is a confirmation between expectations and perceptions which results in satisfaction. In contrast, when service performance is not as good as what the customer expected, there is a negative disconfirmation between expectations and performance which causes dissatisfaction.

\subsection{Empirical Review of the Relationship between Service Quality Dimensions and Customer Satisfaction}

The literature indicates that some researchers have examined the perception of service quality of hotel services. Boonit and Rompho (2012) conducted a study to measure service quality dimensions and compared boutique and hotels in Thailand. The customized service quality model was applied with twenty-nine indicators, on a five-point Likert scale. It was discovered that the quality of service was moderately low, hotels were unable to deliver as promised. In addition, it was found that customer expectation was high on boutique when compared to hotels. In another study by Kariru (2014) on customers' perceptions and expectations of service quality of hotels in Western tourism circuit, in Kenya, it was found that there is need for the hotels to improve their service quality and adapt to customers' expectations. In the study of Shimekit et al. (2016) to show the gap between provided services and expected services and the relationships between service quality and customer satisfaction in terms of five dimensions, namely, tangibility, reliability, responsiveness, confidences and communications in Ethiopia, it was found that there is a negative gap in the perception of service quality across the dimensions. This shows that some hotels operate at low service quality and so there is need to know the aspect of service delivery that they need to improve on.

The relationship between service quality and customer satisfaction has been investigated by several researchers in different industries. Previous studies have considered service quality as an antecedent of customer satisfaction and found a positive relationship between them. For example, Juwaheer and Ross (2003) in their study explored the perception of international tourists about hotel service quality in Mauritius. Nine service quality dimensions, i.e. reliability, assurance, extra room amenities, staff communication and additional amenities sought, room attractiveness and décor, empathy, staff outlook and accuracy, food and service related factors, hotel surroundings and environmental factors were examined. The study 
Journal DOI: www.doi.org/10.46654/ij.24889849

found out that room attractiveness and décor have the strongest impact on perceptions of hotel guest satisfaction, this was closely followed by staff outlook and accuracy, reliability, hotel surroundings, environmental factors, food and service related factors. In a similar study by Hossain (2012) on the impact of perceived service quality on satisfaction of Tourists visiting Bangladesh, five quality dimensions of ServQual were used, i.e. tangibility, reliability, responsiveness, assurance and empathy. It was discovered in the study that the five service quality dimension have positive impact on customer satisfaction. The most prominent factor was empathy, followed by responsiveness, reliability, assurance, and tangibility. In another research carried out by Srinivas and Padma (2013) in Bangalore in India on the impact of service quality on customer satisfaction in the hotel industry. The result of customer expectation showed assurance dimension was at the highest level, followed by empathy, responsiveness, tangibility and reliability, respectively. On the other hand, Shimekit et al. (2016) found responsiveness, reliability, confidence, tangibility and communications respectively. However in the study of Shafiq, Shafique, Din and Cheema (2013) positive relationship between customer satisfaction and three service quality dimensions of assurance, reliability and responsiveness was found but not with empathy and tangibility dimension.

The review reveals that over the years, most of the researchers have found a positive relationship between service quality dimensions and customer satisfaction in the hospitality industry. However, there are differences in the service quality dimensions that influence customer satisfaction. For example, Hossain (2012) found that the most significant service quality dimension that influences customer satisfaction is due to empathy while Srinivas and Padma (2013) found assurance to be the most significant. The differences in the relative significance of the dimensions may be due to the context of the study. Therefore, it is essential to conduct studies in different locations to determine the most critical dimensions for specific areas.

\section{METHODOLOGY}

The population of the study consists of the hotels registered in Osun State with the Jumia travel hotelng.com, website that lists hotels in Nigeria, their location, amenities offered, price, etc. According to hotelng.com, the total number of hotels in Osun State is two hundred and fifty-five (255).

The sample size for this study was determined using Yamane (1964) formula. It is given as: $\mathrm{n}=\frac{N}{1+N(e)^{2}}$

Where $\mathrm{n}=$ Sample size

$\mathrm{N}=$ Population of the study

$\mathrm{e}=$ Level of significance

$=\frac{255}{1+255(0.05)^{2}}$

$=\frac{255}{1+255(0.05)^{2}}$

$=\frac{255}{1+255(0.0025)}$

$=\frac{255}{1+0.6375}$

$=\frac{255}{1.6375} \quad \mathrm{n}=155.73 \cong 156$ 
Therefore, the total number of sampled hotels for the study consists of one hundred and fiftysix (156) hotels. The sample was selected using simple random sampling through balloting while the respondents were selected using convenience sampling technique. This method was used due to the nature of guest in hotels and management's position not to release their guest list.

Data were collected through the use of the questionnaire. The instrument is the modified service quality dimension questionnaire of Parasuraman et al. (1988). The questionnaire consists of three (3) sections made up of forty (40) items. Section A consists of six items, which was based on various demographic factors such as sex, age, occupation, level of education, monthly income, and years of using the hotel. In Section B, the study used the modified SERVQUAL Model to measure service quality. It includes five (5) service quality dimensions namely: tangibility, reliability, responsiveness, assurance and empathy. This section comprises of twenty-six items. Section $C$ was used to measure the dependent variable, which is customer satisfaction with eight (8) items. These items were based on a Likert scale ranging from "Strongly agree (5), Agree (4), Fairly Agree (3), Disagree (2) and Strongly Disagree (1). The validity of the instrument was determined using content validity. In ensuring the instrument's reliability, a pilot study was conducted with thirty (30) customers of Green arcade Hotel in Osogbo, Osun State. At this stage, the respondents were encouraged to provide feedback on the ambiguity (if any) and structure of the questions. The data collected were analyzed using Cronbach's alpha coefficient. The reliability coefficients of the variables in the study are tangibility 0.865 , reliability 0.750 , responsiveness 0.813 , assurance 0.792; empathy 0.834 and customer satisfaction 0.854. Based on the Cronbach alpha coefficients and the suggestion of Lance, Butts and Michaels (2006) that the minimum acceptable reliability coefficient level is 0.7 , the device can be deemed reliable.

\section{DATA ANALYSIS}

Out of the total 624 copies of questionnaire administered, 600 copies representing $96 \%$ were retrieved. Analysis of data collected was conducted using descriptive analysis and multiple regression analysis. 
Journal DOI: www.doi.org/10.46654/ij.24889849

Article DOI: www.doi.org/10.46654/ij.24889849.s7523

4.1 Descriptive Analysis of Respondents Demographic Information

Table 1: Demographic Characteristics of Respondents

\begin{tabular}{|c|c|c|c|}
\hline Items & Characteristics & Frequency & Percentage (\%) \\
\hline \multirow{2}{*}{ Sex } & Male & 362 & 60.3 \\
\hline & Female & 238 & 39.7 \\
\hline \multirow{4}{*}{ Age } & Below 30years & 123 & 20.5 \\
\hline & 31-40years & 205 & 34.2 \\
\hline & 41-50years & 179 & 29.8 \\
\hline & 51years and above & 93 & 15.5 \\
\hline \multirow{5}{*}{ Occupation } & Artisan & 81 & 13.5 \\
\hline & Civil servant & 285 & 47.5 \\
\hline & Student & 52 & 8.6 \\
\hline & Businessman/woman & 136 & 22.7 \\
\hline & Others & 46 & 7.7 \\
\hline \multirow{5}{*}{$\begin{array}{l}\text { Level of } \\
\text { Education }\end{array}$} & SSCE & 31 & 5.2 \\
\hline & NCE/OND & 180 & 30.0 \\
\hline & B.Sc/HND & 289 & 48.2 \\
\hline & M.Sc and above & 62 & 10.3 \\
\hline & Others & 38 & 6.3 \\
\hline \multirow{4}{*}{ Monthly income } & Less than \#100,000 & 86 & 14.4 \\
\hline & $\# 100,000-\# 150,000$ & 149 & 24.8 \\
\hline & $\# 150,000-\# 200,000$ & 215 & 35.8 \\
\hline & $\# 200,000$ and above & 150 & 25.0 \\
\hline \multirow{4}{*}{$\begin{array}{l}\text { Years using the } \\
\text { Hotel }\end{array}$} & Less than 1year & 190 & 31.7 \\
\hline & $1-3$ years & 197 & 32.8 \\
\hline & 4-6 years & 118 & 19.7 \\
\hline & 7 years and above & 95 & 15.8 \\
\hline
\end{tabular}

Source: Field survey (2020)

The results in Table 1 show that out of the 600 respondents 362, representing $60.3 \%$ were male while their female counterparts were 238; representing $39.7 \%$. The result showed that majority of the customers that patronized the hotels were male customers. The results also confirmed that majority of the respondents 205 , representing $34.2 \%$ were within the age bracket of 31 to 40 years. In terms of occupation, the result indicated that $285(47.5 \%)$ respondents were civil servants, followed by businessmen/women (136) representing $22.7 \%$. The educational distribution of the respondents revealed that majority; 289 representing $48.2 \%$ were B.Sc/HND holders, followed by NCE/OND holders, 180 representing $30.0 \%$. Furthermore, the income status of the respondents indicates that majority of the respondents (215) representing 35.8\% earned between N150,000 and N200,000 per month. Finally, the result revealed that about $32.8 \%$ of the respondents have been using the hotels for between one to three years. This outcome implies that the demographic distributions of the respondents is balanced and are therefore suitable to give relevant information relating to the service quality of the selected hotels. 
Journal DOI: www.doi.org/10.46654/ij.24889849

\subsection{Analysis of Research Objectives}

\subsubsection{Perception of Hotel Service Quality}

This objective was achieved through the use of descriptive statistics of frequency, percentage, mean, and standard deviation. The results are presented in Table 2:

Table 2: Summary of Descriptive Statistics of Service Quality Dimensions of the Hotels

\begin{tabular}{|l|l|l|l|l|}
\hline Variables & Frequency & $\begin{array}{c}\text { Percentage } \\
\text { \% }\end{array}$ & Mean & SD \\
\hline Tangibility & 479 & 79.8 & 4.41 & 0.07 \\
\hline Reliability & 426 & 71.0 & 4.5 & 0.11 \\
\hline Responsiveness & 494 & 82.3 & 4.30 & 0.05 \\
\hline Assurance & 428 & 71.4 & 4.22 & 0.04 \\
\hline Empathy & 395 & 65.9 & 4.11 & 0.06 \\
\hline
\end{tabular}

Source: Field Survey (2020)

Table 2 summarizes the various levels of customers' perception of service quality dimensions. The result shows that the perception of responsiveness has the highest value of $82.3 \%$, with mean $=4.30$ and $\mathrm{SD}=0.05$ followed by tangibility $(79.8 \%$, mean $=4.41, \mathrm{SD}=$ $0.07)$, assurance $(71.4 \%$, mean $=4.22 . \mathrm{SD}=0.04)$, reliability $(71 \%$, mean $=4.5, \mathrm{SD}=0.11)$ and empathy $(65.9 \%$, mean $=4.11, \mathrm{SD}=0.06)$. The mean values of all the service quality dimensions are above 4 point. This implies that the level of perception of the service quality of hotels in Osun State is high. However, responsiveness is the most highly rated service quality dimension while empathy is the least rated service quality dimension.

\subsubsection{Level of Satisfaction of Hotel Customers}

This objective was achieved through the use of descriptive statistics of frequency, percentage, mean and standard deviation. The results are presented in Table 3:

Table 3: Summary of Descriptive Statistics of the Level of Satisfaction of Hotel Customers

\begin{tabular}{|l|l|l|l|l|l|l|}
\hline \multirow{2}{*}{ Variables } & \multicolumn{2}{|l|}{ Satisfied } & \multicolumn{2}{l|}{ Dissatisfied } & & \\
\cline { 2 - 6 } & F & $\%$ & F & $\%$ & Mean & $\begin{array}{l}\text { Std. } \\
\text { Dev. }\end{array}$ \\
\hline $\begin{array}{l}\text { Customer } \\
\text { Satisfaction }\end{array}$ & 426 & 70.9 & 174 & 29.1 & & $\mathbf{0 . 1 2}$ \\
\hline
\end{tabular}

Source: Field Survey (2020)

Table 3 shows the frequency distribution of customer satisfaction. 426 (four hundred and twenty-six) respondents representing 70.9\% were satisfied with the hotel services, while 174 representing $29.1 \%$ indicated that they were not satisfied. This implies that majority of the respondents are satisfied with the hotel services in Osun State.

4.4.3: Impact of service quality dimensions (tangibility, reliability, responsiveness, assurance, and empathy) on customer satisfaction

This objective was achieved through the use of multiple regressions analysis. 
Journal DOI: www.doi.org/10.46654/ij.24889849

Article DOI: www.doi.org/10.46654/ij.24889849.s7523

Table 4: Regression Analyses of the Joint Effects of Service Quality Dimensions on Customer Satisfaction

\begin{tabular}{|c|c|c|c|c|c|}
\hline \multirow{2}{*}{ Variables } & \multicolumn{2}{|c|}{$\begin{array}{l}\text { Unstandardized } \\
\text { Coefficients }\end{array}$} & \multirow{2}{*}{$\begin{array}{l}\text { Standardized } \\
\text { Coefficients } \\
\text { Beta } \\
\end{array}$} & \multirow[b]{2}{*}{$\mathbf{T}$} & \multirow[b]{2}{*}{ Sig } \\
\hline & $B$ & $\begin{array}{l}\text { Std. } \\
\text { Error }\end{array}$ & & & \\
\hline (Constant) & -0.913 & 0.58 & & -1.574 & 0.116 \\
\hline Tangibility & 0.375 & 0.056 & 0.272 & 6.682 & 0.000 \\
\hline Reliability & 0.306 & 0.075 & 0.187 & 4.058 & 0.000 \\
\hline Responsiveness & 0.452 & 0.082 & 0.212 & 5.494 & 0.000 \\
\hline Assurance & 0.312 & 0.05 & 0.236 & 6.211 & 0.000 \\
\hline Empathy & 0.857 & 0.063 & 0.489 & 13.596 & 0.000 \\
\hline $\begin{array}{l}R=0.937 \\
R^{2}=0.878 \\
\text { Adj. } R^{2}=0.877 \\
F=766.869 \\
P \text {-value }=0.000\end{array}$ & & & & & \\
\hline
\end{tabular}

Source: Field Survey (2020)

The results in Table 4 present the relative contributions of service quality dimensions (tangibility, reliability, responsiveness, assurance, and empathy) to customer satisfaction of selected hotels in Osun State. The results revealed that tangibility $(\beta=0.272, P<.05)$, reliability, $(\beta=0.187, \mathrm{P}<.05)$, responsiveness $(\beta=0.212, \mathrm{P}<.05)$, assurance $(\beta=0.236$, $\mathrm{P}<.05)$ and empathy $(\beta=0.489, \mathrm{P}<.05)$ have positive impact on customer satisfaction. Furthermore, the results revealed the joint predictions of service quality dimensions on customer satisfaction which were significant at 0.05 level of significance $\left(F=766.869 ; R^{2}=\right.$ 0.878 , Adj. $\left.\mathrm{R}^{2}=0.877 ; \mathrm{P}<.05\right)$. Statistically, the adjusted $\mathrm{R}^{2}$ value of 0.877 signifies the power of the model. It means that the five service quality dimensions can explain $87.7 \%$ of the variations in customer satisfaction. Considering the beta coefficient of each independent variable and its significance level, empathy expresses the strongest impact on customer satisfaction with the highest coefficient value of 0.489 . This was followed by tangibility $(0.272)$, assurance $(0.236)$, responsiveness $(0.212)$ and reliability $(0.187)$ respectively.

\section{Discussion of Findings}

This study adopted the SERVQUAL model to measure the impact of service quality dimensions on customer satisfaction of selected hotels in Osun State. The first objective revealed that responsiveness is the most highly rated service quality dimension. This is in line with the study of Hossain (2012) in Bangladesh where three service quality dimensions namely responsiveness, empathy, and reliability were seen to be the most highly rated service quality dimensions. The second objective indicated that on the average, the respondents were satisfied with the services rendered by the hotels. This is also in line with the work of Choi and Chou (2001) in Hong Kong hotel industry. 
Journal DOI: www.doi.org/10.46654/ij.24889849

Article DOI: www.doi.org/10.46654/ij.24889849.s7523

The third objective examined the impact of service quality dimensions (tangibility, reliability, responsiveness, assurance, and empathy) on customer satisfaction. The results revealed that all the service quality dimensions have significant positive impact on customer satisfaction. Empathy has the strongest impact on customer satisfaction followed by assurance, tangibility, responsiveness and reliability. The findings are supported with the findings of Srinivas and Padman (2013), Juwaheer and Ross (2003), Minh et al. (2015) where the five service quality dimensions were found to have contributed jointly to customer satisfaction in Bangalore, India and Vietnam. However, contrary to the finding of this study that empathy has the highest impact on customer satisfaction, Juwaheer and Ross (2003) found room attractiveness and décor (tangibility), Srinivas and Padman (2013) found assurance while Shimekit et al. (2016) found responsiveness. This implies that location determines the most important service quality dimensions.

\section{CONCLUSION AND RECOMMENDATIONS}

The research has been able to examine the impact of service quality dimensions on customer satisfaction in some selected hotels. Based on the findings, it can be concluded that service quality dimensions such as tangibility, reliability, responsiveness, assurance and empathy are key determinants of customers' satisfaction in the hotel industry. The implication of these findings is that service quality dimensions will have a great influence on customers' decision of the choice of hotel to stay. Therefore, adequate knowledge and implementation of well thought out service quality dimension will not only make a hotel to be more competitive; but also enhance its performance in terms of higher profitability through increased customer patronage.

In view of the above findings and conclusions, the study recommends the following:

i. Management of hotels should focus on improving the five service quality dimensions (tangibility, reliability, responsiveness, assurance and empathy) in order to boost customer satisfaction.

ii. The management of hotels should put in place a feedback mechanism including online platform by which customers can relate their service experience with respect to the five service quality dimensions.

iii. There should be a periodic review of service performance in relation to the five service quality dimensions.

iv. Management should organize training for staff on service quality dimensions and its benefits to customers and the business at large.

v. Finally, hotel operators should ensure that they avoid puffing i.e promises that will unnecessarily raise the expectations of the customers as against the actual quality of service they are able to provide. 
Journal DOI: www.doi.org/10.46654/ij.24889849

Article DOI: www.doi.org/10.46654/ij.24889849.s7523

\section{References}

Boonitt, S. \& Rompho, N. (2012). Measuring service quality dimensions: an empirical analysis of Thai Hotel Industry. International Journal of Business Administration, $3(5), 52-63$.

Chakravarti, B.K. (2011). Hotel accommodation. New Delhi: A. P. H Publishing Corporation

Choi T.Y \& Chou R. (2001). Determinant of hotel customers' satisfaction and repeat patronage in Hong Kong hotel industry. International Journal of Hospitality Management, 20(3), 277- 297.

Cooper, C., Fletcher, J., Fyall, A., Gilbert, D., \& Wanhill, S. (2008). Tourism principles and practice. Essex: Pearson Prentice Hall.

Enlightenme, (2014). Hotel rating, Available: http://enlightenme.com/what-is-the-star-ratingfor-hotels.

European Commission (2014). Hotels and similar accommodation. Available: http://epp.eurostat.ec.europa.eu/statistics explained/index php/Glossary.

Gefan, D. (2002). Customer loyalty in e-commerce. Journal of the Association for Information Systems, 3, 27-51.

Hansen H. \& Sand, J.A (2008). Antecedents to consumer satisfaction with financial services: The moderating effect of the need evaluate, Journal of Financial Services Market, 13(3), 234-244.

Hanzaee, K.H. \& Mirvaisi, M. (2011). Implementing Gronroos service quality model: the role of image and service quality perception on customer satisfaction in the Iran hotel industry. Journal of Basic and Applied Scientific Research, 1(11), 2482-2487.

Hossain, M. J. (2012). Impact of service quality on customer satisfaction: A case of tourism industry in Bangladesh. International Journal of Research in Finance \& Marketing, $2(2), 1-25$.

Jawabreh, O.M., Jahmani, A., Khaleefah, Q.Q., Alshatnawi, E.A. \& Abdelrazaq, H. (2020). Customer expectation in Five Star Hotels in Aqaba Special Economic Zone Authority (ASEZA), International Journal of Innovation, Creativity and Change. 11 (4), 417-438

Jayaraman M., Shankar C. \& Hor W. M. (2010). Service quality delivery and its impact on customer satisfaction in the Banking Sector in Malaysia. International Journal of Innovation, Management and Technology, 1 (4), 398- 404

Jumia Travel, (2019). Hotels in Osun state Nigeria, Available: http:/ / travel.jumia.com/ .

Juwaheer, T. D. \& Ross, D, L. (2003). A study of hotel guest perceptions in Mauritius. International Journal of Contemporary Hospitality Management, 15(2), 105-115

Kariru, A. N. (2014). Customers' perceptions and expectations of service quality in hotels in western tourism circuit, Kenya. Journal of Research in Hospitality, Tourism and Culture, 2(1), 1-12. 
Journal DOI: www.doi.org/10.46654/ij.24889849

Khan, S., Hussain, S. M. \& Yaqoob, F. (2013). Determination of customer satisfaction in fast food industry. European Journal of social sciences and Humanities and management, 6(21), 56-65,

Kotler, P. (2007).Marketing Management. New Jersey: Pearson Prentice Hall.

Kotler, P, \& Lane, K. (2009). Marketing management. New Jersey: Pearson Prentice Hall.

Lance, C. E., Butts, M. M., \& Michels, L. C. (2006). The source of four commonly reported cutoff criteria: What did they really say? Organizational Research Method, 9(2), 202220.

Liu, C. H. \& Tsai, W. S. (2010).The effects of service quality and lifestyle on consumer choice of channel types: The health food industry as an example. African Journal of Business Management, 4(6), 1023-1039.

Lovelock, C. H., Patterson, P. G. \& Walker, R. H. (2001). Service marketing: An AsianPacific perspective. $2^{\text {nd }}$ edition. Australia: Prentice Hall.

Mehra, S. \& Ranganathan, S. (2008). Implementing total quality management with focus on enhancing customer satisfaction. International Journal of Quality and Reliability Management, 25(9), 913- 927.

Méndez-Aparicio M.D, Jiménez-Zarco A, Izquierdo-Yusta A \& Blazquez-Resino, J.J. (2020) Customer experience and satisfaction in private Insurance Web Areas. Frontiers in Psychology, doi: 10.3389/fpsyg.2020.581659

Minh,N., Nguyen, T., Phan, C. A., \& Yoshiki, M. (2015). Service quality and customer satisfaction. A case study of hotel industry in Vietnam. Asian social science journal, 11(10), 73.

Oliver, L. R. (1980). A cognitive model of the antecedents and consequences of satisfaction decision. JMR, Journal of Marketing Research, 17(4), 460.

Oliver, L. R. (1997). Effect of expectation and disconfirmation on post exposure product evaluations: an alternative interpretation, Journal of Applied Psychology, 62(4), 480486.

Osayawe, E. B. (2006), Correlates of customer loyalty to their bank a case study in Nigeria. International Journal of Bank Marketing, 24(7), 494-508.

Parasuraman, A., Zeithaml, V. A., \& Berry, L. L. (1988). SERVQUAL: a multiple item scale for measuring consumer perceptions of service quality. Journal of Retailing, 26(64), $12-37$.

Shafiq, Y., Shafique, I., Din, M. S. \& Cheema, K. R. (2013). Impact of Service quality on customer satisfaction: a study of hotel industry of Faisalabad, Pakistan. MPRA Paper No. 53198, Retrieved from: https://mpra.ub.uni-muenchen.de/53198/

Sheng, J. C. \& Wu, C.Y. (2011). The role of expected future use in relationship based service retention. An International Journal, 21(5), 535-551.

Shimekit, K. E., Wondoson, S. \& Seid, H. A. (2016). Service quality and customer satisfaction in Hospitality Industry: The case of selected hotels in Jimma Town, 
Ethiopia. Global Journal of Management and Business Research: E Marketing, 6 (5), 73-86.

Siddiqui, M. H \& Sharma, T. G. (2010). Analyzing customer satisfaction with service quality in life insurance services. Journal of Targeting, Measurement and Analysis for Marketing, 18, 221-238

Srinivas,P \& Padman, C.(2013). Impact of Service Quality on Customer satisfaction in hotel industry. Journal of Applied Economics and Business, 1(3), 42-64.

Suciptawati, N. L., Paramita, N.L. \& Aristayasa, I.P. (2019). Customer satisfaction analysis based on service quality: case of local credit provider in Bali, Journal of Physics: Conference Series, 1-6

Weitz, B. \& Wensley, R. (2002). Hand book of marketing. London: Sage Publication

West, D., Ford, J. \& Ibrahim E. (2010). Service marketing strategy in strategic marketing: creating competitive advantage, second edition. New York: Oxford press.

Yamane, T. (1964). Statistics: an introductory analysis. New York: Harper and Row

Zhang, X. \& Tang, Y. (2006). Customer perceived e-service quality in online shopping. Master Thesis, Lulea University of Technology. Available: epubl.ltu.se/16530187/2006/06/LTU-PB-EX-0606-SE.pdf

Zeithaml, V, A. \& Bitner, M, J. (2003). Service marketing: integrating customer focus across the firm. New York: McGraw-Hill Higher Education. 